IZA DP No. 3660

How Successful Have Trade Unions Been?

A Utility-Based Indicator of Union Well-Being

J ohn Pencavel

August 2008 


\title{
How Successful Have Trade Unions Been? A Utility-Based Indicator of Union Well-Being
}

\author{
John Pencavel \\ Stanford University \\ and IZA \\ Discussion Paper No. 3660 \\ August 2008 \\ IZA \\ P.O. Box 7240 \\ 53072 Bonn \\ Germany \\ Phone: +49-228-3894-0 \\ Fax: +49-228-3894-180 \\ E-mail: iza@iza.org
}

Any opinions expressed here are those of the author(s) and not those of IZA. Research published in this series may include views on policy, but the institute itself takes no institutional policy positions.

The Institute for the Study of Labor (IZA) in Bonn is a local and virtual international research center and a place of communication between science, politics and business. IZA is an independent nonprofit organization supported by Deutsche Post World Net. The center is associated with the University of Bonn and offers a stimulating research environment through its international network, workshops and conferences, data service, project support, research visits and doctoral program. IZA engages in (i) original and internationally competitive research in all fields of labor economics, (ii) development of policy concepts, and (iii) dissemination of research results and concepts to the interested public.

IZA Discussion Papers often represent preliminary work and are circulated to encourage discussion. Citation of such a paper should account for its provisional character. A revised version may be available directly from the author. 
IZA Discussion Paper No. 3660

August 2008

\section{ABSTRACT}

\section{How Successful Have Trade Unions Been? A Utility-Based Indicator of Union Well-Being*}

Can conventional economic analysis help in defining and measuring the success of labor unions? In this paper, a general indicator of union welfare is proposed and particular expressions for the wage and employment objectives of unions are rearranged to derive measures of union success or welfare. These indicators combine two measures: union density and the relative union-nonunion wage gap. The indicators are applied to describe the movement of union welfare in the United States over the past eighty years, the differences in union success among groups of U.S. workers, and the variation in union well-being across countries.

\section{JEL Classification: J51}

Keywords: $\quad$ trade unions, union density, relative wage effect of unionism, union objectives

Corresponding author:

John Pencavel

Department of Economics

Stanford University

Stanford, CA 94305-6072

USA

E-mail: pencavel@stanford.edu

\footnotetext{
* An earlier version of this paper was presented at the conference on "Institutions and the Labour Market" in Mannheim, March 2007, where helpful comments were received.
} 


\title{
HOW SUCCESSFUL HAVE TRADE UNIONS BEEN ? : \\ A UTILITY-BASED INDICATOR OF UNION WELL-BEING
}

\author{
John Pencavel
}

\section{Introduction}

The conventional model of trade union behavior endows the union with an objective function which is maximized subject to bargaining constraints. ${ }^{1}$ In some respects, this model bears a formal resemblance to the model of consumer behavior in which the consumer is furnished with a utility function which is maximized subject to a budget and perhaps other constraints. Given this apparent partial correspondence, are there features of the theory of consumer behavior that might be exploited to enhance the analysis of unionism?

In particular, the constrained utility-maximizing model of the consumer gives rise to a rich welfare analysis with such concepts as the "true" cost-of-living index number, the compensating variation, and the equivalent variation. These provide measures of changes in consumer welfare. Some concepts are deduced from the consumer's indirect utility function while others use the direct utility function to compare consumption bundles. ${ }^{2}$ One may ask whether, by analogy with the welfare analysis of the consumer, the theory of union behavior can be configured to deliver a welfare analysis of unionism that permits inferences about when union well-being has improved or deteriorated. The parallel between the theory of the consumer's behavior and the theory of union behavior is far from complete. Regardless, is there a welfare analysis for trade union behavior analogous to the welfare analysis of consumer behavior? If so, may we apply this analysis

\footnotetext{
${ }^{1}$ An excellent textbook outlining this model is Booth (1995).

${ }^{2}$ A comprehensive review of different types of welfare measures is contained in Diewert (1981).
} 
to derive indicators of the well-being of unions? This is the principal purpose of this paper: to define and to apply index numbers that provide ordinal measures of the welfare or well-being of the trade union.

The indicator of union well-being below blends two dimensions of unionism: the relative union-nonunion wage differential and union density, the fraction of workers who are union members. The way in which these two dimensions are combined depends on the particular expression of union objectives. Two classes of objective functions are proposed and these are manipulated to generate indices of union well-being. The indicator will sometimes be referred to as a measure of the well-being of unionism or as a measure of the success of trade unions. These are treated as equivalent names for the same indicator.

\section{Conceptual Framework}

\section{A General Statement}

The basic idea is to measure unions' well-being or success by the degree to which unions' wage and employment objectives are satisfied in some state compared with some reference state. Unions typically have many objectives whose importance varies across different unions at a given moment and varies over time for a given union. In this paper, I shall overlook much of this rich detail and focus on unions as a whole although the approach taken here may be applied to a particular union or unions. ${ }^{3}$ A variety of goals have been proposed for unions, but most observers ascribe to unions a special concern with the compensation of their members and their members' employment. In the typical instance, wages and employment constitute two of unionism's principal

\footnotetext{
3 Thus, Dertouzos and Pencavel (1981) constructed an index of well-being for the International Typographical Union.
} 
objectives as befits their members' concerns with their incomes. Hence the objective or utility function of unions is expressed as some function of the wages of union members, $w^{U}$, and their employment, $E^{U}$. In the unions' objective function, $V, w^{U}$ is assumed to be gauged relative to a reference wage, $w^{R}$, and $E^{U}$ is gauged relative to a reference level of employment, $E^{R}$. The empirical analysis below will be conducted in economies where union and non-union sectors of labor markets can be identified and where an a priori case can be made for $w^{R}$ to be given by the wage in the non-union sector, $w^{N}$, and for $E^{R}$ to be given by total employment, $E$. This will permit the unions' utility function to be specified in terms of two arguments: the relative union-nonunion wage gap, $M=\left(w^{U}-w^{N}\right) / w^{N}$, and union density, $D=E^{U} / E$. Denoting union utility or welfare by $V$ and using the subscript 0 to indicate some base or reference state, the unions' objective function may be written for the reference state as

$$
V_{0}\left(w_{0}^{U}, E_{0}^{U}\right)=g\left(M_{0}, D_{0}\right)
$$

where $g($.)denotes a monotone increasing function. In some other state $t$, the unions' well-being or success is indicated by $V_{t}=g\left(M_{t}, D_{t}\right)$ so a natural indicator of the change or the difference in unions' welfare or success is the ratio of $V_{t}$ to $V_{0}$ :

$$
Q_{t}=\frac{V_{t}}{V_{0}}=\frac{g\left(M_{t}, D_{t}\right)}{g\left(M_{0}, D_{0}\right)}
$$

It needs emphasizing that the proposed indicator of unions' well-being or unions' success focuses on outcomes, not on processes. That is, it measures union "utility" in terms of some function of $w^{U}$ relative to $w^{R}$ and of $E^{U}$ relative to $E^{R}$, not on how the values of these variables were 
arrived at. The utility indicator does not consider whether the legal environment is "friendly" to unionism or hostile or neutral. It does not consider whether these outcomes were achieved through legislation in a country's parliament or through centralized bargaining or through decentralized collective bargaining. These issues are not at all irrelevant for the well-being of labor unions; process matters. However, at this stage of the analysis of this topic, it is sufficient to develop an indicator of union welfare or union strength that concentrates on outcomes, not processes.

Even restricted to outcomes and not processes, only two outcomes have been identified: wages and employment. In fact, workers and workers' representatives care about many more outcomes: the level and scheduling of working hours, the degree of security from arbitrary actions of supervisors, the extent of worker participation in shaping their own working environment, working conditions, non-wage monetary benefits, and other concerns. What is done here with wages and employment is necessarily an initial step and is incomplete .

Also observe that unionism's well-being, equation (1), is measured in terms of relative wages and relative employment. This implies, for instance, that an increase in wages that is enjoyed by union and nonunion workers alike, does not raise the unions' welfare. This is consistent with models in which a worker's utility from his wage income is assessed by comparing it with an alternative or comparison wage. Or the union utility function in equation (1) may be interpreted as the union leadership's utility function. The political position of the leadership depends on their performance and the rank-and-file union members are apt to evaluate their leadership's performance by comparing their union wages with those of a comparison set of workers, perhaps nonunion workers.

2. A Particular Expression for Union Objectives: the Stone-Geary

One formalization is to write the unions' ordinal objective or utility function as 


$$
V\left(w^{U}, E^{U}\right)=\left(\frac{w^{U}}{w^{R}}\right)^{\theta}\left(\frac{E^{U}}{E^{R}}\right)^{1-\theta} .
$$

Equation (3) is called the Stone-Geary function because of its resemblance to the work on linear expenditure systems in consumer demand analysis. ${ }^{4}$ If $0 \leq \theta \leq 1$, then the higher the value of $\theta$, the greater the importance of relative wages in union objectives compared with relative employment.

Make the important assumptions that, for the United States, the reference wage $w^{R}$ is the wage earned by comparable non-union workers $w^{N}$ and the reference employment $E^{R}$ is given by total employment, $E$, in which case equation (3) becomes

$$
V\left(w^{U}, E^{U}\right)=\left(\frac{w^{U}}{w^{N}}\right)^{\theta}\left(\frac{E^{U}}{E}\right)^{1-\theta} .
$$

Given the relative union-nonunion wage gap is $M=\left(w^{U}-w^{N}\right) / w^{N}$ and union density is $D=E^{U} / E$, the previous equation may be written

$$
V\left(w^{U}, E^{U}\right)=(1+M)^{\theta}(D)^{1-\theta} .
$$

This states that union utility or union success rises with the union-nonunion wage gap, $M$, and with union density, $D$. Write the previous equation for the base state 0 and for another state $t$ and, as in equation (2) above, form $Q_{t}$ as the ratio of $V_{t}$ to $V_{0}$ :

${ }^{4}$ In the research on union behavior, objective functions similar to equation (3) were first used by Dertouzos and Pencavel (1979) for the International Typographical Union (ITU) where the index of union well-being (for the ITU) is constructed from the ratio of $V_{t}$ to $V_{0}$. In this instance, the union's indirect utility function forms the basis for this index. 


$$
Q_{t}^{S G}=\frac{V_{t}}{V_{0}}=\left(\frac{1+M_{t}}{1+M_{0}}\right)^{\theta}\left(\frac{D_{t}}{D_{0}}\right)^{1-\theta}
$$

$Q_{t}^{S G}$ is the indicator of union well-being or union success corresponding to a Stone-Geary (SG) expression of unionism's objectives. $Q_{t}^{S G}$ depends on magnitudes that are, in principle, observable: first, $Q_{t}^{S G}$ is a positive function of the relative union-nonunion wage gap in state $t$ compared with the gap in state 0 ; second, it depends positively on union density in $t$ compared with union density in 0 . The relative weight on the wage gap and on union density depends on the value of $\theta$ (where $0 \leq \theta \leq 1$ ) such that higher values of $\theta$ imply a greater weight on the union-nonunion wage differential. In calculating values for $Q_{t}^{S G}$, we shall posit different values for $\theta$.

3. A Particular Expression for Union Objectives: Expected Utility

Under some key assumptions, the expected utility of the median union member may be written as

$$
V\left(w^{U}, E^{U}\right)=\left[\varphi\left(w^{U}\right)-\varphi\left(w^{R}\right)\right] \cdot \frac{E^{U}}{E^{R}}
$$

where $\varphi($. $)$ denotes the utility function of the median union member. ${ }^{5}$ As before, suppose that the nonunion wage constitutes the reference wage $\left(w^{R}=w^{N}\right)$ and suppose that total employment represents reference employment $\left(E^{R}=E\right)$. Also assume a linear logarithmic utility function $\varphi(w)$ $=\gamma \cdot \log (w)$ in which case the unions' objective function in base state 0 may be expressed as

\footnotetext{
${ }^{5}$ In published empirical research on behavioral models of unionism, the expected utility formulation of union objectives dates from Farber (1978). Early references are contained in Oswald (1985).
} 


$$
V_{0}\left(w_{0}^{U}, E_{0}^{U}\right)=\gamma\left[\log \left(\frac{w_{0}^{U}}{w_{0}^{N}}\right)\right] \cdot \frac{E_{0}^{U}}{E_{0}}=\gamma\left[\log \left(1+M_{0}\right)\right] \cdot D_{0}
$$

Write equation (8) for state $t$, form the ratio of $V_{t}$ to $V_{0}$, and take antilogarithms ${ }^{6}$ to arrive at the indicator of union well-being corresponding to an expected utility expression of union objectives, $Q_{t}^{E U}:$

$$
\frac{\exp \left(V_{t}\right)}{\exp \left(V_{0}\right)}=Q_{t}^{E U}=\frac{\left(1+M_{t}\right)}{\left(1+M_{0}\right)} \cdot \frac{\exp \left(D_{t}\right)}{\exp \left(D_{0}\right)}
$$

Note that $Q_{t}^{E U}$ is independent of the value of $\gamma$. It is the counterpart of equation (6) which expresses union objectives in the Stone-Geary form. Note that, for values of $D_{t}$ less than about one-quarter, approximately $e^{D}=1+D$. This means that, when $D$ is less than 0.25 , an approximate index of union well-being implied by the expected utility expression for union objectives is

$$
Q_{t}^{E U X}=\frac{\left(1+M_{t}\right)}{\left(1+M_{0}\right)} \cdot \frac{\left(1+D_{t}\right)}{\left(1+D_{0}\right)}
$$

where the $X$ in the superscript of $Q_{t}^{E U X}$ indicates that this is an approximation to the exact index in equation (9). Is equation (10) a useful approximation to equation (9) ? This will be determined shortly.

Each indicator $Q_{t}^{S G}, Q_{t}^{E U}, Q_{t}^{E U X}$ expresses union success or union well-being as an ordinal index that combines two variables: the union-nonunion wage gap and union density. The combination of these two variables is not arbitrary but is an implication of the characterization of

\footnotetext{
${ }^{6}$ The union objective function is assumed to be ordinal so that monotone increasing transformations (such as logarithmic) of the function that preserve the ordering are permissible.
} 
the form of the union "utility" function. The particular way in which the union-nonunion wage gap and union density are combined into one index depends on initial assumptions about the form of union objectives. Equation (10) suggests an especially simple way of measuring union well-being: in state $t$ and state 0 , form the product of one plus the union-nonunion wage gap and one plus union density and divide the product value for $t$ by the product value for 0 .

We now provide three applications of these utility-inspired indicators of union success or union well-being. The first application is to derive an index of union success in the U.S. economy over time. The second is to describe the variation across demographic groups or sectors of the economy in the success of U.S. unions at a given moment. The third is a cross-country analysis of the well-being or success of unionism among those countries for which wage extension rules are sufficiently uncommon that there is a meaningful distinction between the unionized and non-unionized sectors of the economy.

III. Applications of the Utility-Based Indicator of Union Success 1. The United States over Time, 1922-2005

The first application is to derive an index that describes the evolution of union success in the United States from the First World War to the present. ${ }^{8}$ The base state 0 is set for the year 1977 so $Q_{t}^{S G}=Q_{t}^{E U}=Q_{t}^{E U X} 1$ in 1977. The index (equation (6)) from the Stone-Geary functional form for union objectives is graphed in Figure 1 where the four series shown correspond to different

\footnotetext{
${ }^{8}$ For the United States, the sources of information for the union-nonunion wage gaps are, from 1922 to 1977, Lewis (1963) as reproduced and updated by Pencavel and Hartzog (1984). After 1977, wage gaps are those compiled by Hirsch and Macpherson (2007). Information about union density in the United States from 1922 to 1977 is from Troy and Sheflin (1985) and, after 1977, it is from Hirsch and Macpherson (2007). Lewis calculated wage gaps for groups of years (1920-24, 1925-29, 1930-34, 1935-39, 1940-44, 1945-49, 1950-54, 1955-59,1960-64) and I have retained his grouping. Later years are as follows: 1965-69, 1970-74, 1977, 1982, 1987, 1992, 1997, 2002, and 2005.
} 
assumptions about the value of $\theta$ in forming $Q_{t}^{S G}$. The solid line in Figure 1 corresponds to the case when $\theta$ is assumed to be one-third; the dotted line shows $Q_{t}^{S G}$ when $\theta$ is assumed to be two-thirds; the dashed line corresponds to $\theta=0.10$; and the starred line corresponds to $\theta=0.90 . Q_{t}^{S G}$ appears to exhibit greater volatility when $\theta$ is one-third and one-tenth and this reflects the relatively greater variation over time in union density compared with the union-nonunion wage gap. An audacious generalization from the empirical research on union objectives (Pencavel (1991, Ch. 3) is that U.S. unions tend to place a greater relative weight on employment which, if correct, would make the indices corresponding to $\theta=1 / 3$ and $\theta=1 / 10$ the more relevant ones.

Regardless of the value of $\theta$, union success reached its zenith in the U.S. from the late 1940 s to the early 1970 s since when there has been a steady decline. When $\theta=1 / 3$, U.S. unions in 2005 were about two-thirds as successful as they were in 1977 . When $\theta=2 / 3$, U.S. unions in 2005 were about three-quarters as successful as they were in 1977. The difference in these estimates of the decline in union well-being reflects the fact that union density has fallen more than the unionnonunion wage gap and a heavier weight is placed on union density when $\theta=1 / 3 .^{9}$

Figure 2 graphs the indices (equations (9) and (10)) of union success as implied by the expected utility functional form for union objectives. Again, the reference state 0 is given by the year 1977 when $Q_{t}^{E U}=Q_{t}^{E U X}=1$. According to $Q_{t}^{E U}$, U.S. union well-being was greatest in the late 1950s and early 1960s when the index is some twelve percent greater than the base year 1977. In 2005, this indicator of union well-being places union success at about 88 percent of that in 1977. This contraction from 1977 to 2005 in union well-being as implied by $Q_{t}^{E U}$ is similar to that implied by $Q_{t}^{S G}$ when $\theta=2 / 3$. According to both $Q_{t}^{S G}$ and $Q_{t}^{E U}$, by 2005, unionism in the U.S. is less

\footnotetext{
${ }^{9}$ This cardinalization of the indicator of union success requires stronger assumptions about union objectives than have been made. This is one reason to trace the consequences of different functional expressions for union objectives and for the derived indicator of union well-being.
} 
successful than it has been since the 1920s. In fact, $Q_{t}^{E U}$ suggests union well-being in 2005 was eighty-seven percent of its 1920s well-being. It is as if the legislation of the National Labor Relations Act that was designed in part “to encourage collective bargaining” had never been enacted.

It is also evident from Figure 2 that the approximation $Q_{t}^{E U X}$ closely follows the exact series $Q_{t}^{E U}$ so the approximate formula, equation (10), provides a simple and convenient way of tracking the movements over time in union well-being.

2. Union Strength in the United States by Demographic and Sectoral Attributes in 2005

Now suppose that the base state 0 corresponds to "all workers" in the U.S. and assume $t$ varies across different groups of workers. Then the indicators $Q_{t}^{S G}, Q_{t}^{E U}$, and $Q_{t}^{E U X}$ measure union success across different workers compared with union success for workers as a whole. For this, we use the union-nonunion wage gaps and union density calculated for White men, Black men, White women, Black women, private sector employees, and public sector employees in 2005. ${ }^{10}$ The implied indicators of union well-being for these workers are reported in Table 1.

The union movement in the U.S. has been least successful for White women and most successful for Black men. White women have lower union-nonunion wage gaps and lower union density than the other groups so their low ranking is expected. The relative success of unionism for Black workers corroborates Ashenfelter’s (1972) results . Using information on union density and union-nonunion wage gaps, as in this paper, Ashenfelter (1972, p.462) concluded "there is .....less discrimination against Black workers in the average unionized labor market than in the average nonunion labor market”.

Union-nonunion wage gaps are lower for public sector workers than those for private

\footnotetext{
${ }^{10}$ These data are drawn from Hirsch and Macpherson (2007).
} 
workers while union density is considerably higher for public than private sector workers. The difference in union success between public and private sector workers is greatest if $\theta$ assumes low values in which case differences in union density receive a heavier weight.

The expected utility indices imply rankings similar to those for the Stone-Geary objective function. Again, the values of the approximation $Q_{t}^{E U X}$ are close to those for the exact values of $Q_{t}^{E U}$.

3. Union Success across Countries in the 1990s

Where have trade unions been successful and where have they languished? To address this question, consider the same indicators but now applied across countries. The base state 0 will be the United States in the early 1990s and the data on union densities and on union-nonunion wage gaps will also refer to years in the early to mid-1990s. ${ }^{11}$ The countries whose values of union success are computed will be those for which distinct union and nonunion sectors can be identified and a plausible case can be made for the nonunion wage being the wage in the absence of unionism. That is, we shall restrict our comparisons to those countries for which the reference wage may be given by the nonunion wage $\left(w^{R}=w^{N}\right)$. These are countries in which extension rules play a modest role in wage-setting: U.S., Australia, Britain, Canada, New Zealand, and Japan. ${ }^{12}$

The indicators of union success across countries are given in Table 2. According to all indicators, U.S. unions are the least successful even though the union-nonunion wage gap in the U.S. exceeds that in other countries except for Japan. Because this wage gap in the United States

\footnotetext{
${ }^{11}$ The data on union-nonunion wage gaps and union density are drawn from Blanchflower (1996).

${ }^{12}$ Certain extension rules did exist in these countries but they are not so pervasive as those in Continental Europe. Of course, even without extension rules, there are several reasons why nonunion wages in these countries may diverge from wages in the absence of unionism in the economy. However, the empirical importance of these reasons has not been established with confidence except in some particular cases.
} 
applies to a relatively small fraction of the work force, these $Q$ indicators rank the union movement in the U.S. as the least successful among these six countries. In the early to mid-1990s, British unionism is the most successful. This is attributable to a relatively high union density in Britain of 39 percent (which has since declined, of course) and to an estimated union-nonunion wage gap of 15 percent. The union-nonunion wage gap reported for Japan of 26 percent is the principal reason for Japan being ranked as having relatively successful unions by the indicator $Q_{t}^{E U}$ and by $Q_{t}^{S G}$ with $\theta=0.9$

The relative standing of U.S. unionism will not surprise scholars. However, when $\theta$ is relatively high and for $Q_{t}^{E U X}$, unionism in Canada, Australia, and New Zealand, was only a little more successful than U.S. unionism and this may be less unexpected. There have been some important changes in the law regulating unionism in some of these countries and values of $M$ and $D$ for the first decade of this century may alter the relative position of union success in these countries.

\section{Conclusions}

This paper suggests that Economics can provide some guidance in determining which unions or which union movements have been successful and which have not. These indicators of union well-being rest on the conventional characterization of unions as being concerned with their members' wage and employment outcomes. The indicators combine measures of union density and of the union-nonunion wage gap. Clearly, if unions have goals that embrace other outcomes such as work hours, then the analysis here would have to be altered. In addition, the approach in this paper would have to be modified for those economies where union-negotiated wage scales apply to many nonunion workers so that union-nonunion wage gaps are small and where union density 
sharply understates the scope of union-negotiated agreements. In principle, however, this framework could encompass this.

The computed indicators of trade union well-being imply that U.S. unions were most successful in the 1950s and 1960s and their well-being in the first decade of the twenty-first century is little different from that in the 1920s when unionism was struggling to gain a foothold. U.S. unions appear to have been more successful for Black workers and especially for Black men. Comparing U.S. unionism with that in countries whose labor markets resemble those in the U.S., even though union-nonunion wage gaps in the U.S. are high compared with union-nonunion wage differentials elsewhere, the extent of unionism in the U.S. is so small that unions are judged as least successful in the U.S. Unionism in Canada and Australia is only slightly more successful than that in the U.S. In the 1990s, among these six countries, unionism was most successful in Britain.

Finally, a word about methodology. The indicators proposed and constructed here are a logical consequence of the assumptions made. In the same way as measurements of compensating variation and of "true" cost-of-living index numbers are logical applications of the theory of consumer demand and contain no more falsifiable implications than are embodied in the theory of demand so the indicators of trade union well-being in this paper have no more falsifiable predictions than the model of trade union behavior on which they rest. ${ }^{13}$

It may be asked, why are these indicators of trade union well-being or success rather than indicators of, say, trade union strength. Because higher union density and larger unionnonunion wage gaps are sometimes viewed as noisy signals of union power, it is perfectly

\footnotetext{
${ }^{13}$ The model of union behavior exploited in this paper has a number of falsifiable implications. For instance, one sharp prediction is that, if unions maximize their rents and if unions and firms negotiate efficient contracts, employment will be independent of wages. See Brown and Ashenfelter (1986). More on the comparative statics of these models is contained in Booth (1995), Oswald (1985), and Pencavel (1991).
} 
understandable if some would prefer to call the indices in this paper indicators of trade union strength. Often scholars describe unionism as "strong” when a relatively large fraction of workers are union members or are covered by union-negotiated collective bargaining agreements (Bowdler and Nunziata (2007), Layard, Nickell, and Jackman (1991, pp.3-4), Rees (1989, Ch. 13)) although they may also look at other signals of "strength" such as the coordination of bargaining and the use of two-tier wage systems that distinguish between the pay of new hires and that of workers inherited from the past. Other scholars follow the Webbs $(1897$, p.816) who suggested that wage outcomes were a necessary part of defining powerful unions. In other words, the two key variables in this paper, union density and wage differentials, have been used by others to identify strong or weak unionism. In the past, however, no-one has proposed the particular ways in which union density and union-nonunion wage gaps are combined in this paper. These combinations follow from some simple assumptions about the form of union objectives . 


\section{REFERENCES}

Ashenfelter, Orley. 1972. “Racial Discrimination and Trade Unionism”, Journal of Political Economy, Vol. 80, No. 3, Part 1, (May/June), pp. 435-64.

Blanchflower, David G. 1996. “The Role and Influence of Trade Unions in the OECD”, Centre for Economic Performance Discussion Paper No. 310, October.

Booth, Alison L. 1995. The Economics of the Trade Union , Cambridge: Cambridge University Press.

Bowdler, Christopher, and Luca Nunziata. 2007. “Trade Union Density and Inflation Performance: Evidence from OECD Panel Data”, Economica , Vol 74, No. 293, (February), pp. 135-159.

Brown, James N. and Orley Ashenfelter. 1986. “Testing the Efficiency of Employment Contracts.” Journal of Political Economy. Vol. 94, No. 3, Part 2, pp. S40 - S87 .

Dertouzos, James N., and John H. Pencavel. 1981. "Wage and Employment Determination under Trade Unionism: the International Typographical Union”, Journal of Political Economy, Vol. 89, No. 6 (December), pp. 1162-81.

Diewert, W.Erwin.1981. “The Economic Theory of Index Numbers: A Survey”. In Angus Deaton, ed., Essays in the Theory and Measurement of Consumer Behaviour in Honour of Sir Richard Stone, London: Cambridge University Press, pp. 163-208. 
Farber, Henry S. 1978. "Individual Preferences and Union Wage Determination: The Case of the United Mine Workers”, Journal of Political Economy, Vol. 68, October. pp. 923-42.

Hirsch, Barry T. and David A. Macpherson, 2007. Union Membership and Earnings Data Book, Washington, D.C.: The Bureau of National Affairs, Inc.

Layard, Richard, Stephen Nickell, and Richard Jackman. 1991. Unemployment: Macroeconomic Performance and the Labour Market Oxford: Oxford University Press.

Lewis, H. Gregg. 1963. Unionism and Relative Wages in the United States Chicago: University of Chicago Press.

Oswald, Andrew J. 1985. “The Economic Theory of Trade Unions: An Introductory Survey.” Scandinavian Journal of Economics, Vol. 87 No. 2, June, pp. 160-93.

Pencavel, John H. 1991. Labor Markets under Trade Unionism. Oxford: Basil Blackwell.

Pencavel, John H. and Catherine E. Hartsog. 1984. “A Reconsideration of the Effects of Unionism on Relative Wages and Employment in the United States, 1920-1980" Journal of Labor Economics Vol. 2, No. 2 , April, pp. 193-232.

Rees, Albert. 1989. The Economics of Trade Unions. Chicago: University of Chicago Press third ed. 
Troy, Leo, and Neil Sheflin. 1985. Union Sourcebook: Membership, Structure, Finance, Directory. first edition, Industrial Relations Data Information Services, NJ 07052.

Webb, Sidney and Beatrice Webb. 1897. Industrial Democracy. London: Longmans. 
Figure 1

$Q^{S G}$ : Index of Union Success for the United States, 1922-2005

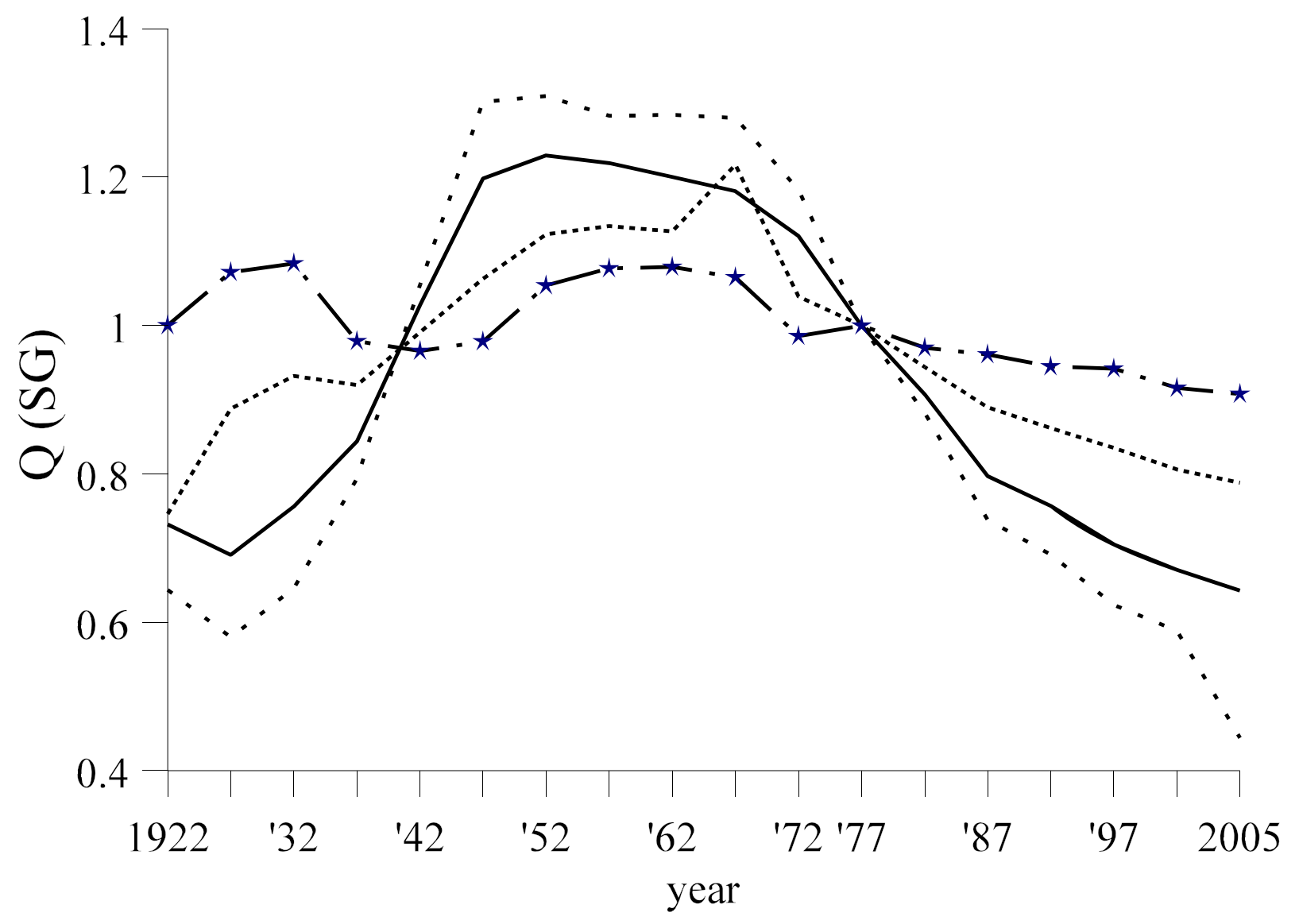

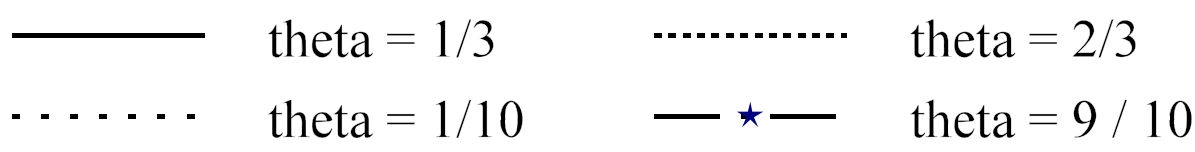


Figure 2

$Q^{E U}$ and $Q^{E U X}$ : Indices of Union Well-being for the United States, 1922-2005

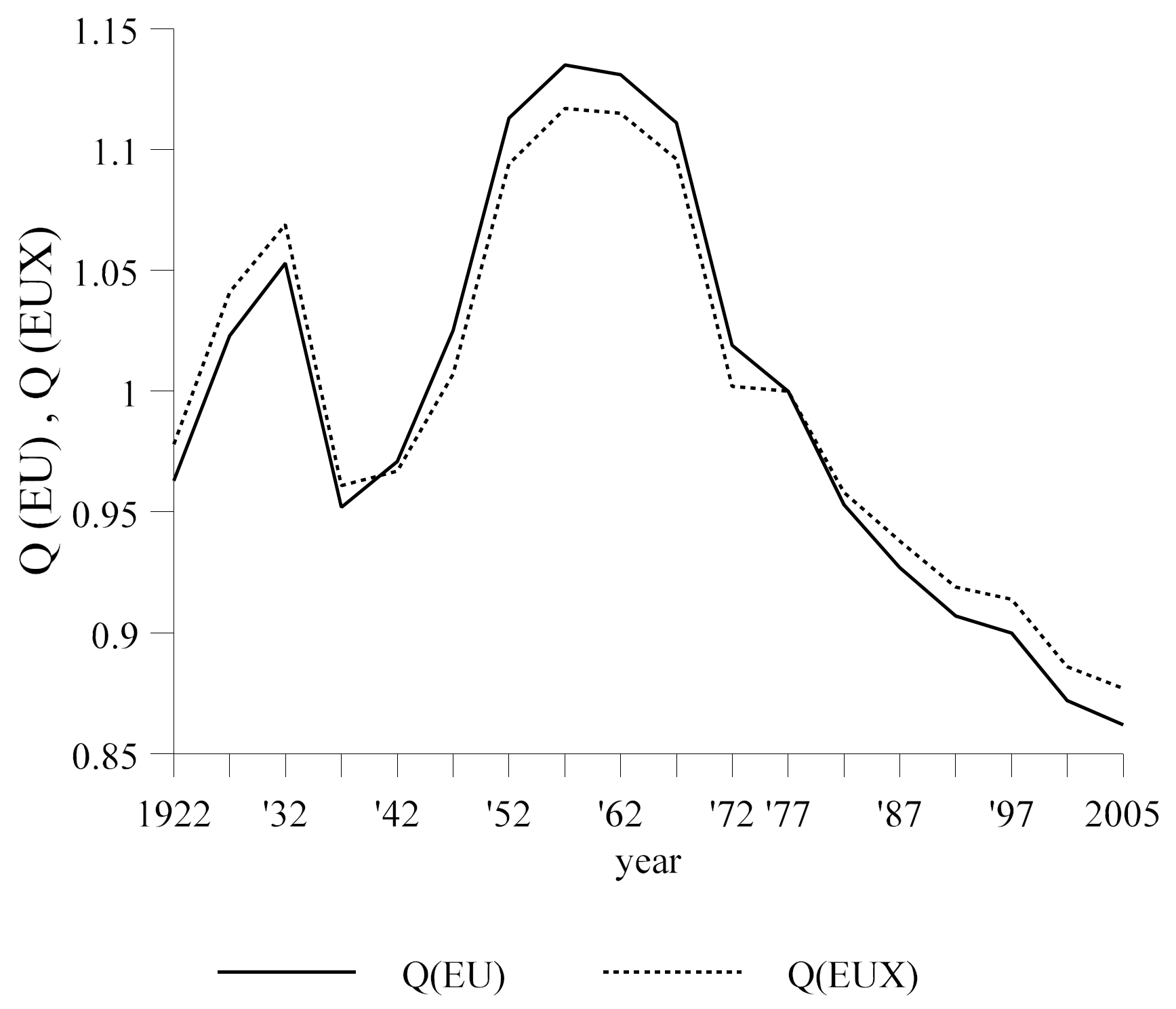


Table 1 : Union Success by Type of Workers, United States in 2005

\begin{tabular}{|l|c|c|c|c|c|c|}
\hline & \multicolumn{4}{|c|}{$Q^{S G}$} & \multirow{2}{*}{$Q^{E U}$} & \multirow{2}{*}{$Q^{E U X}$} \\
\cline { 2 - 5 } & $\theta=1 / 10$ & $\theta=1 / 3$ & $\theta=2 / 3$ & $\theta=9 / 10$ & & \\
\hline All workers & 1 & 1 & 1 & 1 & 1 & 1 \\
\hline White men & 1.07 & 1.06 & 1.05 & 1.05 & 1.05 & 1.05 \\
\hline Black men & 1.26 & 1.20 & 1.12 & 1.06 & 1.08 & 1.07 \\
\hline White women & 0.88 & 0.91 & 0.95 & 0.98 & 0.98 & 0.98 \\
\hline Black women & 1.13 & 1.10 & 1.07 & 1.04 & 1.05 & 1.05 \\
\hline Private sector & 0.66 & 0.74 & 0.88 & 1.00 & 1.00 & 1.01 \\
\hline Public sector & 2.62 & 2.03 & 1.41 & 1.09 & 1.24 & 1.18 \\
\hline
\end{tabular}


Table 2: Union Success across Countries in the 1990s

\begin{tabular}{|c|c|c|c|c|c|c|}
\hline & \multicolumn{4}{|c|}{$Q^{S G}$} & \multirow[t]{2}{*}{$Q^{E U}$} & \multirow[t]{2}{*}{$Q^{E U X}$} \\
\hline & $\theta=1 / 10$ & $\theta=1 / 3$ & $\theta=2 / 3$ & $\theta=9 / 10$ & & \\
\hline U.S.A. & 1 & 1 & 1 & 1 & 1 & 1 \\
\hline Australia & 2.03 & 1.67 & 1.26 & 1.03 & 1.15 & 1.10 \\
\hline Canada & 2.15 & 1.73 & 1.26 & 1.01 & 1.14 & 1.09 \\
\hline Japan & 1.48 & 1.36 & 1.20 & 1.10 & 1.16 & 1.14 \\
\hline New Zealand & 1.77 & 1.50 & 1.18 & 1.00 & 1.07 & 1.04 \\
\hline U.K. & 2.27 & 1.83 & 1.33 & 1.07 & 1.23 & 1.17 \\
\hline
\end{tabular}

